\title{
Elemental analysis of cetacean skull lesions associated with nematode infections
}

\author{
S. Pascuall ${ }^{1, *}$, E. Abollo $^{1}$, A. López ${ }^{2}$ \\ ${ }^{1}$ Area de Parasitología, Grupo PB2, Facultad de Ciencias, Universidad de Vigo, Aptdo. 874, 36200 Vigo, Spain \\ ${ }^{2}$ Coordinadora para o Estudio dos Mamíferos Mariños Anxeríz 8, $5^{\circ}$ D, Milladoiro, 15895 Ames, La Coruña, Spain
}

\begin{abstract}
The elemental composition of both healthy and eroded cetacean skulls associated with nematode infections was evaluated. A total of 27 samples of eroded and non-eroded prepared museum cetacean skulls were characterised by elemental (CHN), X-ray fluorescence, and X-ray diffraction methods. The inorganic composition and crystal line structure (hydroxylapatite-like minerals) were similar for both types of skull samples, but the CHN values clearly differed. The results suggest that the carbon-rich fraction is lost in eroded areas, probably as a result of glycosaminoglycan-degrading Crassicauda enzymes.
\end{abstract}

KEY WORDS: Cetacean $\cdot$ Skull lesions $\cdot$ Crassicauda Resale or republication not permitted without written consent of the publisher

\section{INTRODUCTION}

Nematodes infesting tissues and organs of cetaceans are most commonly members of the family Crassicaudidae (Dailey 1985). In numerous cases Crassicauda infections are believed to produce lesions in the skull of cetaceans, primarily in members of the Delphinidae (Dailey \& Perrin 1973, Robineau 1975, Dailey \& Stroud 1978, Dailey \& Walker 1978, Perrin \& Power 1980, Raga et al. 1982). Bone lesions have been reported in both stranded and captured dolphins in different oceans and seas of the world (Dailey \& Perrin 1973, Raga et al. 1982). The absence of residual bone lesions in older animals has been interpreted as strong evidence indicating that parasitism may constitute a major factor in the natural mortality of small cetaceans (Perrin \& Powers 1980, Walker \& Cowan 1981, Geraci \& St. Aubin 1987). Whatever the proximate cause of mortality, understanding the causal relationships concerning parasiticcaused skull lesions will require a better understanding of both the host lesion and the associated parasites. Recently, a long-term macroscopic examination of cetacean cranial gross lesions in specimens from the coast of Galicia (NW Spain), an important stranding area

*E-mail: spascual@correo.uvigo.es
(López et al. 1998), allowed us to carry out an elemental analysis of skull lesions which appeared as eroded areas in prepared museum skulls.

\section{MATERIAL AND METHODS}

A total of 27 prepared museum skulls belonging to immature bottle-nosed dolphins Tursiops truncatus were macroscopically examined for skull lesions (Table 1). Trabecula-like bone lesions consisting of sunken surfaces with duct systems, $10 \times 5$ to $50 \times 40 \mathrm{~mm}$ in size in the orbitary (frontal-orbitosphenoid) skull region, were classified as eroded areas (Fig. 1). Noneroded bone areas were also sampled as controls. For each specimen, a comparison of eroded to non-eroded skull areas was made.

Eroded and non-eroded skull samples obtained following the procedure of Benneth \& Oliver (1992) were examined by X-ray fluorescence and X-ray powder diffraction to determine the composition of the inorganic fraction and its single crystal line structure. Measurements were carried out on a Siemens D-5000 powder diffractometer at room temperature using graphite-monochromatized $\mathrm{CuK}_{\alpha 1}, 2$ radiation $(\lambda=$ $1.54056 \AA$ ). The skull organic composition was esti- 
Table 1. Tursiops truncatus. Data of samples used for elemental analysis of skull lesions. TBL: total body length in $\mathrm{cm}$; M: male; F: female; SL: skull length in mm; SW: skull width in mm; Sample location; CEMMA: Coordinadora para o Estudio dos Mamíferos Mariños; SGHN: Sociedade Galega de Historia Natural

\begin{tabular}{|c|c|c|c|c|c|c|c|}
\hline Date & Locality & TBL & Sex & SL & SW & No. of lesions & Location \\
\hline$-/-/ 1983$ & Esmelle & 230 & - & 480 & 256 & 1 & SGHN \\
\hline 10 Nov 1990 & Xuño & 265 & - & 500 & 258 & 0 & CEMMA \\
\hline 30 Dec 1990 & Santa Mariña & - & - & 370 & 280 & 6 & CEMMA \\
\hline 31 Dec 1990 & Louro & 290 & M & 515 & 272 & 2 & CEMMA \\
\hline 06 Jan 1991 & Queiruga & 287 & M & 510 & 283 & 3 & CEMMA \\
\hline 03 Feb 1991 & P. Langost. & 265 & M & 510 & 283 & 0 & CEMMA \\
\hline 02 Jun 1991 & M. do Rostro & - & - & 256 & 270 & 0 & CEMMA \\
\hline 13 Nov 1991 & S. Xurxo & 250 & M & 500 & 274 & 1 & SGHN \\
\hline 12 Jan 1992 & M. do Rostro & 275 & $\mathrm{~F}$ & 470 & 265 & 2 & CEMMA \\
\hline 24 May 1992 & Seaia & - & - & 430 & 225 & 0 & CEMMA \\
\hline 18 Jul 1992 & Ponzos & 275 & F & 530 & 285 & 6 & SGHN \\
\hline 11 Sep 1992 & Sanxenxo & 132 & - & 310 & 160 & 0 & CEMMA \\
\hline 27 Nov 1992 & Bouzas & 278 & M & 459 & 260 & 2 & CEMMA \\
\hline 12 Apr 1993 & Sobreira & 268 & M & 475 & 270 & 5 & CEMMA \\
\hline 30 Jul 1993 & Patos & 205 & M & 425 & 220 & 0 & CEMMA \\
\hline 05 Jul 1994 & As Sinas & 268 & $\mathrm{~F}$ & 500 & 275 & 0 & CEMMA \\
\hline 23 Jun 1994 & Cee & 206 & M & 420 & 250 & 0 & CEMMA \\
\hline 21 Jan 1995 & Lago & 268 & $\mathrm{~F}$ & 430 & 270 & 0 & CEMMA \\
\hline 15 Jun 1995 & Soesto & 244 & M & 495 & 270 & 2 & CEMMA \\
\hline 03 Jun 1995 & Baldaio & 287 & $\mathrm{~F}$ & 555 & 295 & 4 & CEMMA \\
\hline 23 Apr 1996 & Ferrol & 220 & M & 450 & 282 & 0 & SGHN \\
\hline 20 Oct 1996 & Louro & 249 & M & 485 & 260 & 1 & CEMMA \\
\hline 24 Oct 1996 & Lapaman & 280 & M & 525 & 270 & 1 & CEMMA \\
\hline 06 Jan 1997 & Corrubedo & 154 & - & 440 & 278 & 3 & CEMMA \\
\hline 17 Jul 1997 & Niñons & - & - & 490 & 290 & 0 & CEMMA \\
\hline 02 Nov 1997 & Oia & - & - & 510 & 270 & 1 & CEMMA \\
\hline 24 Nov 1997 & Oia & 276 & - & 506 & 268 & 1 & CEMMA \\
\hline
\end{tabular}

mated by CHN analyses obtained with an elemental microanalyzer, Carlo Erba Eager 200. Statistical differences in the CHN composition between both healthy and eroded skull samples were assessed using an SPSS WIN 7.5 paired Student's $t$-test.

\section{RESULTS}

Lesions were observed in $59.25 \%$ of the skulls sampled (range: 0 to 6 lesions in each specimen). Most of the lesions occurred as eroded areas in the frontalorbitosphenoid and pterygoid regions (Fig. 2), with nasal and orbitary perforations extending into the brain cavity.

Calcium and phosphate minerals were predominant in the inorganic phase of both skull homogenates (Table 2). The powder X-ray diffraction patterns revealed that these calcium phosphate hydroxyde compounds had crystal line structures similar to that of hydroxylapatite, HPA $\left[\mathrm{Ca}_{10}\left(\mathrm{PO}_{4}\right)_{6}(\mathrm{OH})_{2}\right]$ (Fig. 3), which constitutes the main inorganic phases of the hard tissues of vertebrates. X-ray diffraction patterns of all skull samples were characteristic of moderately crystalline minerals as obtained in a unique crystalline phase.

Table 3 shows the results of the CHN analyses. The carbon percentage in eroded areas was $24 \%$ lower than in non-eroded areas $(t=-8.71 ; \mathrm{p}<0.05)$. The $\mathrm{CHN}$ (i.e., organic phase) mean composition was $33.18 \%$ of the total skull sample in non-eroded areas, whereas

Table 2. Tursiops truncatus. X-ray fluorescence analysis of inorganic elements (mean $\pm \mathrm{SD})$ in non-eroded $(\mathrm{n}=11)$ and eroded $(n=16)$ skull samples

\begin{tabular}{|lcc|}
\hline Element $(\%)$ & Non-eroded & Eroded \\
\hline $\mathrm{Na}$ & $0.0964 \pm 0.01$ & $0.0868 \pm 0.01$ \\
$\mathrm{Mg}$ & $0.4240 \pm 0.02$ & $0.3920 \pm 0.01$ \\
$\mathrm{Al}$ & $0.0690 \pm 0.00$ & $0.0866 \pm 0.00$ \\
$\mathrm{Si}$ & $0.1560 \pm 0.02$ & $0.2190 \pm 0.03$ \\
$\mathrm{P}$ & $22.600 \pm 0.01$ & $22.600 \pm 0.01$ \\
$\mathrm{~S}$ & $0.0381 \pm 0.00$ & $0.0456 \pm 0.00$ \\
$\mathrm{Cl}$ & $0.2310 \pm 0.00$ & $0.2430 \pm 0.00$ \\
$\mathrm{~K}$ & $0.0554 \pm 0.00$ & $0.0562 \pm 0.00$ \\
$\mathrm{Ca}$ & $33.100 \pm 0.39$ & $33.000 \pm 0.47$ \\
$\mathrm{Zn}$ & $0.0805 \pm 0.00$ & $0.0763 \pm 0.00$ \\
$\mathrm{Sr}$ & $0.0361 \pm 0.01$ & $0.0363 \pm 0.02$ \\
$\mathrm{Fe}$ & - & $0.0265 \pm 0.00$ \\
\hline
\end{tabular}



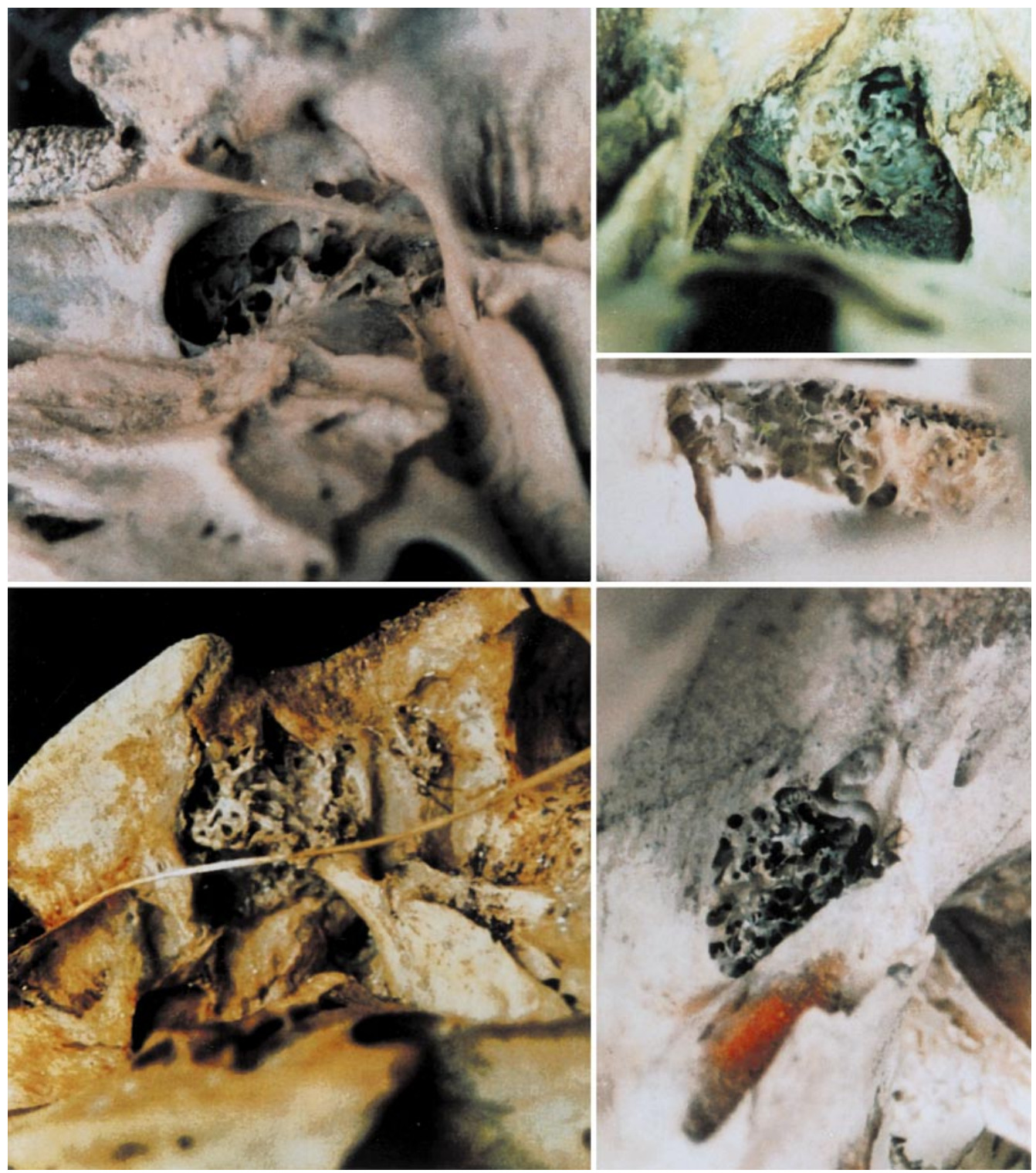

Fig. 1. Tursiops truncatus. Trabecula-like bone lesions classified as eroded samples for the elemental analysis of skull lesions

this percentage decreased to $27.16 \%$ in eroded ones $(t=-7.56 ; \mathrm{p}<0.05)$. Values for the $\mathrm{C}: \mathrm{N}$ ratio were also significantly different from different eroded and noneroded skull samples $(t=-19.29$; $\mathrm{p}<0.01)$.

\section{DISCUSSION}

Impure forms of HPA, the main mineral of bone and teeth of vertebrates (Bigi et al. 1995), constituted the main inorganic phases of both eroded and non-eroded skull samples. Since HPA skull crystal structures were similar in healthy and eroded skull areas, macroscopic lesions are probably due to altered organic phases in cranial soft tissues. In fact, the $\mathrm{C}: \mathrm{N}$ ratio (an index be- lieved to reflect the quantity of carbon-rich molecules relative to the quantity of protein; Ferron \& Leggett 1994) revealed a decreased composition of the carbon fraction in eroded skull samples. In the extracellular matrix (ECM), major constituents are collagens, noncollagenous glycoproteins and proteoglycans (Kreis \& Vale 1993). Within the ubiquitous proteoglycans found on cell surfaces, the glycosaminoglycan (GAG) polysaccharides side chains represents more than $5 \%$ of the organic composition of a given bone in an adult mammal (Kreis \& Vale 1993). While proteins (N-rich molecules) have a $\mathrm{C}: \mathrm{N}$ ratio near 3.0 (Harris et al. 1986), GAGs are carbohydrate structures; thus, when these extended sugar chains are present, it is expected that the ratio will increase to a value above 3.0. In 


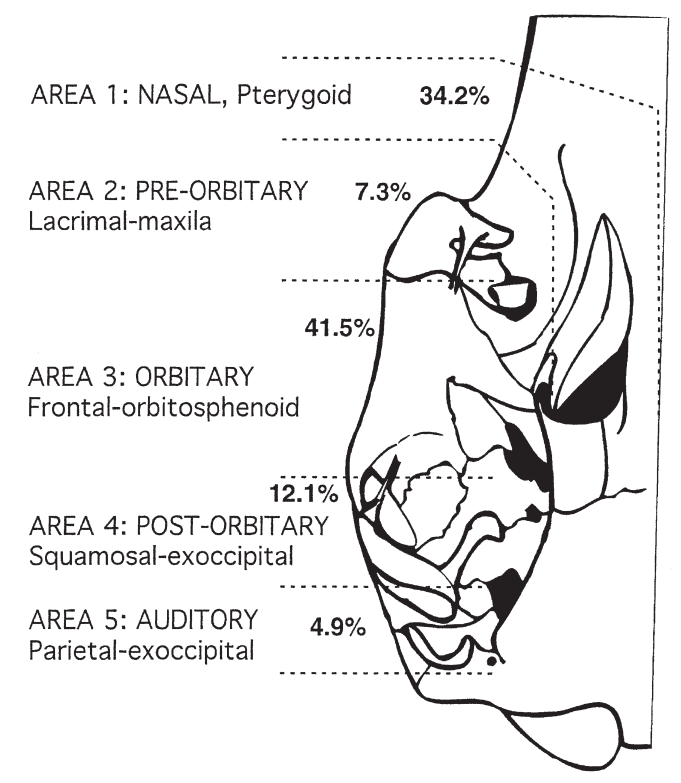

Fig. 2. Tursiops truncatus. Frequency of lesions within each area on the ventral skull surface

eroded-skull samples, a C:N ratio was found close to 3.0 , which was almost $1 / 2$ of that of non-eroded samples, probably as a consequence of parasite-caused GAG hydrolisation by chondroitinase-like enzymes. Although at present this hypothesis is still rather speculative, other factors support it: (1) Susceptibility of GAGs to digestion by certain bacterial enzymes has traditionally formed an important biochemical criterion by which GAGs are classified (Kreis \& Vale 1993); (2) Crassicauda spp. infections have frequently been recorded associated with skull lesions during routine necropsies on cetacean carcasses (López et al. 1998); (3) GAG-degrading parasitic enzymes which degrade hyaluronic acids and chondroitin sulphates have been recorded in numerous Nematoda (Sakanari \& Mckerrow 1990, Hotez et al. 1994); (4) in migrating Nematoda excretory-secretory (ES) parasitic enzymes are recognised to play an important role in invading host tissues (Fukuda et al. 1990); and (5) adult nematodes use polysaccharides as an energetic substrate (Köhler \& Voight 1988). Therefore, it could be that when GAGs are hydrolysed, eroded areas become evident macro-

Table 3. Tursiops truncatus. CHN determination (mean $\pm \mathrm{SD}$ ) in non-eroded $(\mathrm{n}=11)$ and eroded $(\mathrm{n}=16)$ skull samples

\begin{tabular}{|lrr|}
\hline & Non-eroded & \multicolumn{1}{c|}{ Eroded } \\
\hline Nitrogen (\%) & $3.55 \pm 0.08$ & $5.17 \pm 0.06$ \\
Carbon $(\%)$ & $25.38 \pm 0.32$ & $18.88 \pm 1.01$ \\
Hydrogen $(\%)$ & $4.25 \pm 0.03$ & $3.11 \pm 0.21$ \\
C:N ratio & $7.15 \pm 0.25$ & $3.65 \pm 0.24$ \\
\hline
\end{tabular}

scopically due to physical migration of parasitic nematodes through the ECM.

Although the data herein reported provide a better understanding of skull lesions, obviously further research is needed. This is especially true concerning in vivo cultivation of mature Crassicauda adults to biochemically characterise any GAG-degrading parasitic enzyme in the ES nematode products. Furthermore, the collection of fresh fixed cranial tissues (carcasses with Condition 2 as defined by Kuiken \& Garcia-Hartmann 1991) is desirable in order to study the tissue and cytochemical structures in both eroded and noneroded skull areas. Moreover, because of problems associated with the biological interpretation of the C:N
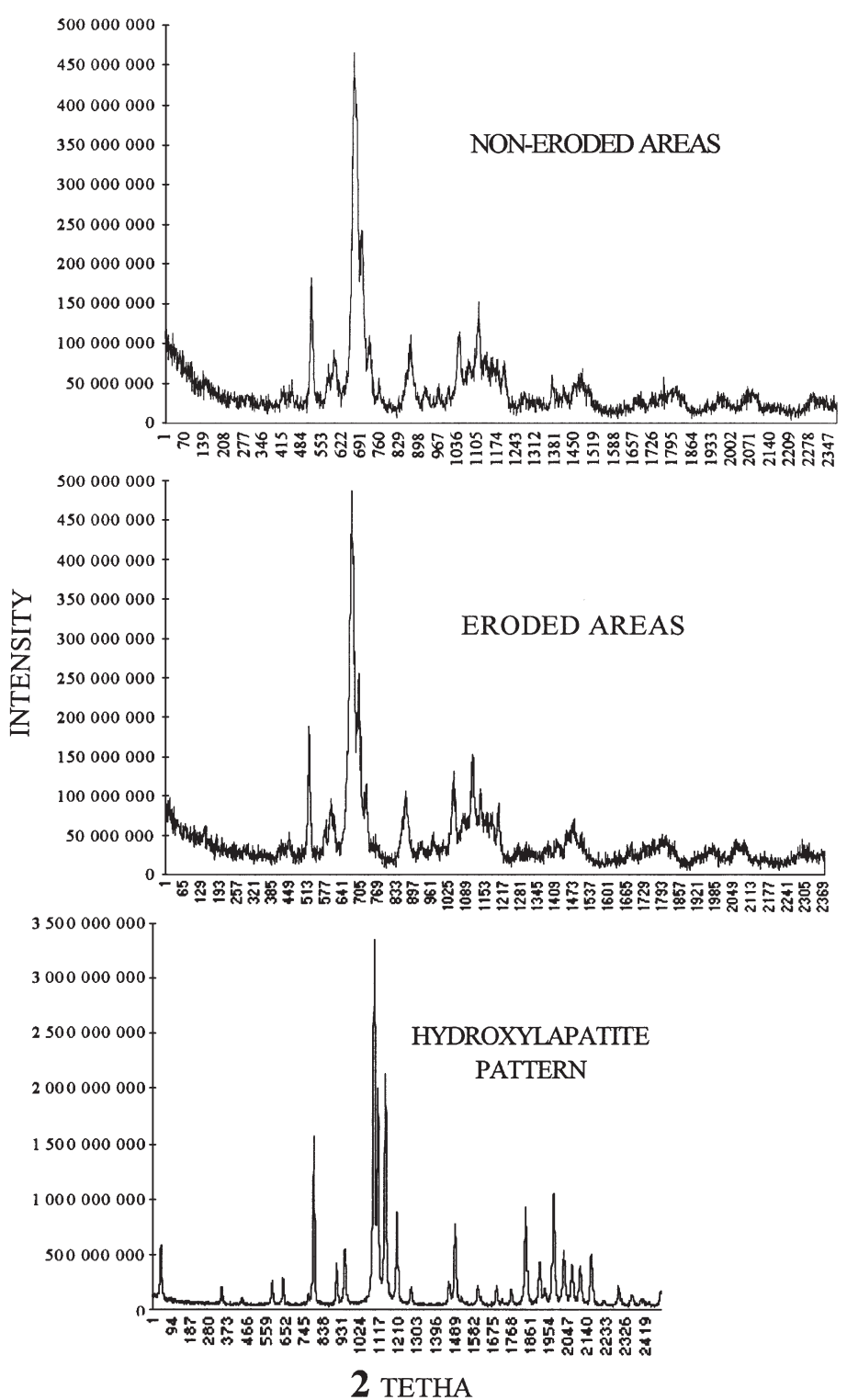

Fig. 3. Tursiops truncatus. Powder X-ray diffraction patterns of the skull samples as compared with hydroxylapatite 
ratio (Ferron \& Leggett 1994) simultaneous measurements of all major molecules are needed in order to assess carbon-nitrogen mobilisation accurately. Finally, while Crassicauda nematodes have traditionally been recorded associated with skull lesions, other bacteria and/or viruses may also be present as single or sympatric infections. The existence of multiple etiological agents has also been previously suggested for other parasite-caused diseases in cetaceans (Abollo et al. 1998). A complete etiological examination of eroded skull samples is, therefore, also desirable to delineate the potential role of disease on cetacean mortality and stranding behaviour.

Acknowledgements. We wish to thank the Consellería de Educación e Ordenación Universitaria, Xunta de Galicia, for financial assistance under Project XUGA 30110A97. Thanks are also due to Jorge Millos and Sonia Escudero (CACTI-Universidad de Vigo) for technical assistance.

\section{LITERATURE CITED}

Abollo E, Gestal C, López A, González AF, Guerra A, Pascual S (1998) Squid as trophic bridges for parasite flow within marine ecosystems: the case of Anisakis simplex (Nematoda: Anisakidae), or when the wrong way can be right. In: Payne AIL, Lipinski MR, Clarke MR, Roeleveld MAC (eds) Cephalopod biodiversity, ecology and evolution, Vol 20. South African Journal of Marine Science, Cape Town, p 223-232

Benneth H, Oliver GI (1992) XRF analysis of ceramics, minerals and allied materials. Wiley \& Sons, New York

Bigi A, Foresti E, Gandolfi M, Gazzano M, Roveri N (1995) Inhibiting effect of zinc on hydroxylapatite crystallization. J Inorg Biochem 58:49-58

Dailey MD (1985) Diseases of Mammalia: Cetacea. In: Kinne $\mathrm{O}$ (ed) Diseases of marine animals, Vol IV, Part 2. Biologische Anstalt Helgoland, Hamburg, p 805-844

Dailey MD, Perrin WF (1973) Helminth parasites of porpoises of the genus Stenella in the eastern tropical Pacific, with description of two new species: Mastigonema stenellae gen. et sp. n. (Nematoda: Spiruroidea) and Zalophotrema pacificum sp. n. (Trematoda: Digenea). Fish Bull US 71: 455-471

Dailey MD, Stroud RK (1978) Parasites and associated pathology observed in cetaceans stranded along the Oregon coast. J Wild Dis 14:503-511

Dailey MD, Walker WA (1978) Parasitism as a factor in single

Editorial responsibility: Murray Dailey,

Sausalito, California, USA strandings of southern California cetaceans. J Parasitol 64: $593-596$

Ferron A, Leggett WC (1994) An a appraisal of condition measures for marine fish larvae. Adv Mar Biol 30:217-303

Fukuda T, Tongu Y, Ishii A (1990) Ultrastructural changes in the oesophagus, intestine, and excretory organ of larval Anisakis (Ascaridoidea: Nematoda) after incubation in artificial gastric juice. Jpn J Parasitol 39:1-6

Geraci JR, St Aubin DJ (1987) Effects of parasites on marine mammals. Int J Parasitol 17:407-414

Harris RK, Nishiyama T, Paul AJ (1986) Carbon, nitrogen and caloric content of eggs, larvae, and juveniles of the walleye pollock, Theragra chalcogramma. J Fish Biol 29:87-98

Hotez P, Cappelo M, Hawdon J, Beckers C, Sakanari J (1994) Hyaluronidases of the gastrointestinal invasive nematodes Ancylostoma caninum and Anisakis simplex: possible functions in the pathogenesis of human zoonoses. J Infect Dis 170:918-926

Köhler P, Voight KP (1988) Nutrition and metabolism. In: Melhorn H (ed) Parasitology in focus. Springer, Berlin, p 412-453

Kreis T, Vale R (1993) Guidebook to the extracellular matrix and adhesion proteins. Sambrook \& Tooze Publication at Oxford University Press, Oxford

Kuiken T, García-Hartmann M (1991) Proceedings of the first ECS workshop on Cetacean pathology: dissection techniques and tissue sampling. ECS (Ecol Comp Ser) Newsl 17(Spec issue):1-35

López A, Valeiras X, Pascual S, Abollo E, Díaz JI (1998) Skull lesions associated with Crassicauda spp. (Nematoda, Crassicaudidae) in cetaceans stranded on the Galician coast (NW Spain). Eur Res Cet, 12. Proceedings of the Twelfth Annual Conference of the ECS, Monaco, p 342-347

Perrin WF, Power JE (1980) Role of nematode in natural mortality of spotted dolphins. J Wildl Manag 44:960-963

Raga JA, Casinos A, Filella S, Raduan MA (1982) Notes on cetacens of the Siberian coasts. V. Crassicauda grampicola Johnston and Mawson, 1941 (Nematoda) cause of injuries in the pterygoids of some specimens of Grampus griseus. Säugetierkd Mitt 30(4):315-318

Robineau D (1985) Lésions osséus lies ala présence du genre Crassicauda (Nematoda: Spiruroidea) sur la face ventrale díun crane do Tursiops truncatus (Cetacea, Delphinidae). Ann Soc Sci Nat 6:93-97

Sakanari JA, Mckerrow JH (1990) Identification of the secreted neutral proteases from Anisakis simplex. J Parasitol 76: $625-630$

Walker WA, Cowan DF (1981) Air sinus parasitism and pathology in free-ranging common dolphins (Delphinus delphis) in the eastern tropical Pacific. Administrative Report No. LJ-81-23C. Nat Mar Fish Serv Southw Fish Center, La Jolla, CA

Submitted: November 15, 1999; Accepted: April 3, 2000

Proofs received from author(s): July 13, 2000 